\title{
Primary production, biomass and abundance of phototrophic picoplankton in the Mediterranean Sea: a review
}

\author{
Giuseppe Magazzù ${ }^{1}$, Franco Decembrini ${ }^{2}$ \\ ${ }^{1}$ Department of Biology, University of Lecce, via Provinciale Monteroni, Lecce, Italy \\ ${ }^{2}$ Istituto Sperimentale Talassografico CNR, Sp. San Raineri, I-98122 Messina, Italy
}

\begin{abstract}
In the Mediterranean Sea, the contribution of picophytoplankton to primary production varies from $31 \%$ (Straits of Messina, with an average total production of $0.18 \mathrm{mg} \mathrm{C} \mathrm{m}^{-3} \mathrm{~h}^{-1}$ ) to $92 \%$ (Ionian Sea, with an average of $1.64 \mathrm{mg} \mathrm{C} \mathrm{m}^{-3} \mathrm{~h}^{-1}$ ). Although studies have used different methodologies, the contribution of this small phototrophic fraction to whole ${ }^{14} \mathrm{C}$ assimilation seems to be more important in oligotrophic off-shore waters (71\%) compared to the neritic ones $(44 \%)$. Diluting effects of fluvial waters (Adriatic Sea) and hydrodynamic phenomena (Straits of Messina) probably influence the physiologic activity of these populations. Picophytoplankton contribution to primary production in brackish and eutrophic environment is clearly lower than in marine waters both in terms of chl $a$ and of ${ }^{14} \mathrm{C}$ assimilation. Reports of cellular abundance (Cyanobacteria and eucaryotic cells) ranged from $10^{5}$ to $10^{8}$ cells $\mathrm{I}^{-1}$ with a mean value of $10^{7}$ showing no difference between seasons and suggesting a state of particular equilibrium for this population in the planktonic community. Recent data on prochlorophyte cellular density are of the same order of magnitude $\left(10^{7}\right.$ cells $\left.1^{-1}\right)$ of other picophytoplanktonic procaryotic and eucaryotic organisms.
\end{abstract}

KEY WORDS: Picophytoplankton · Primary production - Biomass - Mediterranean Sea

\section{INTRODUCTION}

The presence of extremely small algae in marine environments has been known since the beginning of this century, and Lohmann (1911) coined the term 'nanoplankton' for those algae that escaped through the meshes of common phytoplankton nets.

The term 'picoplankton' was introduced by Sieburth et al. (1978) for those organisms that can pass through $2.0 \mu \mathrm{m}$ membranes and that are retained by filters with $0.2 \mu \mathrm{m}$ porosity. Due to their small size, description of their internal and external structure required electron microscopic (EM) techniques. Data gathered using EM techniques not only allowed precise definition of the morphology of Cyanobacteria and eucaryotic algae, as Prasinophyceae and Chlorophyceae, but also confirmed the hypothesis that photosynthetic picoplank- ton, or 'picophytoplankton' as proposed by Fogg (1986), is composed of both procaryotic and eucaryotic cells characterized by their autofluorescence (Johnson \& Sieburth 1982)

In the present work, the term picophytoplankton will be used for procaryotic and eucaryotic organisms with dimensions inferior to $3.0 \mu \mathrm{m}$ which carry out oxygenic photosynthesis independent of their taxonomic position; the term indicates both their dimensions (pico) and their function as autotrophs (photoautotrophs).

Using the flow cytometry technique in the last 5 to 6 yr very small (diameter 0.6 to $0.8 \mu \mathrm{m}$ ) red fluorescing cells have been detected near the bottom of the euphotic zone (Chisholm et al. 1988, Li \& Wood 1988, Neveu et al. 1989) in the Atlantic and Pacific Oceans and in the Sargasso Sea. These organisms, classified as picophytoplankton because of their size, were de- 
scribed as coccoid procaryotes and assigned to Prochlorophyta on the basis of their pigment composition (divinyl-chl $a$ and -chl $b$, alpha-carotene and zeaxanthin) which is different from that of other picoplanktonic procaryote and eucaryote cells. Their presence during winter in the Mediterranean Sea has been ascertained by Vaulot et al. (1990). The study of these organisms and their role in the Mediterranean ecosystem therefore offers a new and promising research branch.

Compared to the great number of results published worldwide on distribution and ecology of picophytoplankton, information on regional (different basins) and temporal (annual cycles) distribution of biomass and production in the Mediterranean Sea is very scarce, and even less is known about the role played by picophytoplankton in this ecosystem and in the marine food web.

The present work reviews mainly the results available on ${ }^{14} \mathrm{C}$ assimilation, chl a and cell abundance; further research will hopefully focus on ecophysiological aspects.

\section{RESULTS AND DISCUSSION}

Most studies concerned the Western Basin; data from 3 sites of the eastern areas of the Mediterranean exist and 3 works were carried out in Adriatic waters (Fig. 1). Three studies were conducted in brackish Sicilian environments. Finally 1 article (Berland et al. 1990) describes the presence of picoplanktonic cells in deep (120 to $150 \mathrm{~m}$ ) and ultraoligotrophic waters of the Eastern Basin, but does not mention numerical data on this fraction.

Table 1 lists all the values concerning primary production, biomass and cellular density that have been gathered during the last $10 \mathrm{yr}$ in different areas of the Mediterranean Sea. The values are reported chronologically and grouped according to the areas and cruises. Both surface and euphotic layer sampling were considered, including coastal and off-shore areas with different trophic levels.

In order to separate different fractions, filters with 25,5 and $1 \mu \mathrm{m}$ porosity were used in some studies (e.g. Ibarra 1981), which makes it difficult to compare the results with those obtained using $2.0 \mu \mathrm{m}$ filters. Similar problems exist when comparing other studies (Berman et al. 1984, Chepurnova \& Gutveyb 1988, Gilmartin \& Revelante 1988, Raimbault et al. 1988a) for which filters with meshes measuring $2.5 \mu \mathrm{m}$ (Chepurnova \& Gutveyb 1988) and $3.0 \mu \mathrm{m}$ were used. In terms of biomass and primary production, the present work groups the fraction $<3.0 \mu \mathrm{m}$ and one measuring $<2.0 \mu \mathrm{m}$ used by almost all authors from 1990 on. It would be useful to estimate the contribution of the $2.0-3.0 \mu \mathrm{m}$ fraction, however, the fraction measuring 1.0-0.2 $\mu \mathrm{m}$ seems to represent about $85 \%$ of the total picophytoplankton production and biomass (e.g. Decembrini \& Magazzù 1990).

\section{Contribution of picophytoplankton to primary production}

The contribution of picophytoplankton to primary production ranges from a minimum of $31 \%$ in the Straits of Messina, an area with strong hydrodynamism where the average value of total primary production is $1.19 \mathrm{mg} \mathrm{C} \mathrm{m} \mathrm{C} \mathrm{h}^{-3}$, to a maximum of $92 \%$ in the Ionian Sea, off the Sicilian coasts where the average value of primary production is $1.73 \mathrm{mg} \mathrm{C} \mathrm{m}^{-3}$ $\mathrm{h}^{-1}$. The relative contribution of picophytoplankton to primary production in the Mediterranean Sea seems to be more important in off-shore waters than in coastal waters; this is in accordance to Li \& Platt (1987) who in the world's oceans found a higher contribution in oligotrophic waters and a lower one in nutrient-rich waters. Furthermore, picophytoplankton activity is generally higher far from bloom time, a period when the fraction $>2.0 \mu \mathrm{m}$ seems to prevail.

Table 2 lists the percentage of assimilation of picophytoplankton in different areas of the Mediterranean Sea. The mean value of its contribution to the total production is $65 \%$; this value reaches $71 \%$ in pelagic environments (P) and drops to $44 \%$ in neritic environments $(\mathrm{N})$. When total picophytoplank-

Fig. 1 Mediterranean Sea: location of studied areas for picophytoplankton 
ton $(0.5$ to $2.0 \mu \mathrm{m})$ is divided into fractions: the portion measuring from 0.5 to $1.0 \mu \mathrm{m}$ (probably Cyanobacteria and Prochlorophytes) is much more productive, whereas the portion measuring from 1.0 to $2.0 \mu \mathrm{m}$ (probably the eukaryotic fraction) is less active (about 10 to $15 \%$ ) but constant in most of the studied environments (Magazzù et al. 1989a).

The results obtained in the Straits of Messina deserve some particular consideration. The contribution of the $<1.0 \mu \mathrm{m}$ fraction of picophytoplankton measured during the different cruises ranged from 31 to $92 \%$. Such a broad range could be ascribed to the varying chemico-physical conditions in the Straits of Messina where strong nutrient-rich upwelling currents (Vercelli \& Picotti 1926) from the Ionian Sea alternate with superficial $\mathrm{P}$ - and $\mathrm{N}$-poor waters from the Tyrrhenian Sea. Sampling was carried out in conditions of strong turbulence (1982) and in the core of Tyrrhenian waters (1986) which formed the surface layer.

\section{Contribution of picophytoplankton to biomass and cellular density}

The biomass values, expressed as chl $a$, are as variable as ${ }^{14} \mathrm{C}$ assimilation values and range from $28 \%$ in the Straits of Messina to $85 \%$ in the Northern Adriatic Sea. Generally, when the concentration of total biomass increases rapidly, the picophytoplankton contribution tends to augment slowly. Particularly in oligotrophic waters with low chl a values $\left(<1.0 \mathrm{\mu g} \mathrm{l}^{-1}\right)$ the smallest fraction forms a high percentage of the total biomass, whereas it decreases in eutrophic waters where the contribution of bigger oganisms furnishes more chl a. Raimbault et al. (1988a) suggested that the different size-fractions exhibit different maximum stocks, with chl a concentration of each size class not exceeding maximum values of $0.5,1.3,2.0 \mu \mathrm{g} \mathrm{l}^{-1}$ for the fractions measuring $<1 \mu \mathrm{m},<3 \mu \mathrm{m}$ and $<10 \mu \mathrm{m}$, respectively.

Such results support a hypothesis that the picophytoplanktonic biomass is stationary, whereas temporal variations in total biomass are due to larger cells. In this regard, it is noteworthy that one of the first studies realized in Mediterranean waters reported a mean contribution of 22 to $25 \%$ of the $<1 \mu \mathrm{m}$ fraction to the total biomass independent of sampling period and hydrographic conditions (Ibarra 1981).

A limited amount of data is available on the vertical distribution of picophytoplankton. Delgado et al. (1992) described the vertical distribution of chl $a$ and the picophytoplankton contribution in the Northwestern Mediterranean Sea. Data exist from the Algerian Basin and Ligurian Sea (Raimbault et al. 1988a), the
Adriatic Sea (Gilmartin \& Revelante 1988) and the Straits of Messina (Magazzù et al. 1989a).

Taken together, these data, obtained in conditions of marked or moderate water stratification, suggest the presence of 2 distribution models. In the first model (Raimbault et al. 1988a), the minimum contribution of the picophytoplankton fraction is situated at the maximum chl a concentration, whether superficial, subsuperficial or deep. The same conclusion is suggested by the results obtained by Delgado et al. (1992) stating that the picophytoplankton contribution to biomass (illustrated in Fig. 9 of the article) seems to be always lower at the Deep Chlorophyll Maximum which is located between 45 and $50 \mathrm{~m}$. The second model (Gilmartin \& Revelante 1988) is based on results obtained in the Adriatic Sea under stratified water column conditions and states that picoplankton dominates in subsurface chl-maximum' and that it 'is caused by increases in this fraction' $(<3.0 \mu \mathrm{m})$. This is in contrast to the cell abundance and total cell volume prevailing in the superficial layer. Even if the authors explain this difference between vertical chl a distribution and cell abundance by the presence of 'differences of technical bias in epifluorescent enumeration', the discrepancy with the first model (Raimbault et al. 1988 b) is apparent.

In the Straits of Messina, the situation is more complex because of the particular hydrodynamics due to tidal currents which induce strong upwelling phenomena which bring colder and saltier intermediate lonian waters to the surface. The upwelling produces a strong turbulence within the whole water column; in these conditions vertical distribution patterns of the picophytoplankton were observed that could be based on either of the 2 described models: the chl a maximum is generally present between 25 and $50 \mathrm{~m}$ and undergoes vertical changes depending on the intensity of upwelling of the deep waters. The maximum contribution of picophytoplankton to total biomass alternates its position but is generally located in superficial waters and occasionally at deeper levels where the deep chl a maximum is situated. In both cases, induction and maintenance of the intense production of the system seems to be due to the effects of biostimulation due to the upwelling of nutrient-rich waters. In any case, it is always the upwelling that regulates the raising and lowering of thermocline and of the layers where the 2 maximum values are measured (total chl $a$ and percent of picophytoplankton biomass) that depend on the different residence times of upwelling waters in the euphotic layer.

Considering the results as a whole (Table 2), the mean value for chl $a$ is $59 \%$, and there is a small difference between pelagic $(57 \%)$ and neritic ( $64 \%)$ environments. 
Table 1. Summary of size-fractionated biomass, production and cell density of picophytoplankton in the Mediterranean Sea

\begin{tabular}{|c|c|c|c|c|c|c|}
\hline Location & & $\begin{array}{c}\left.\mathrm{Chla} \mathrm{a}^{-3}\right) \\
\left(\mathrm{mg} \mathrm{m}^{-3}\right)\end{array}$ & $\left(\mathrm{mg} \mathrm{C} \mathrm{m}^{-3} \mathrm{~h}^{-1}\right)$ & $\begin{array}{l}\text { Picophytoplankton } \\
\text { (cells })^{-1} \text { ) }\end{array}$ & Source $^{a}$ & Comments \\
\hline $\begin{array}{l}\text { Eastern Medit. (Israel coast) } \\
(1981-1982)\end{array}$ & $\begin{array}{l}\operatorname{Max} \\
\%\end{array}$ & $\begin{array}{c}10.8-14.4\left(\mathrm{mg} \mathrm{m}^{-2}\right) \\
60-80\end{array}$ & $\begin{array}{l}2.5-9.2 \\
25-90\end{array}$ & & (1) & $<3 \mu \mathrm{m}$ \\
\hline $\begin{array}{l}\text { Straits of Messina } \\
\text { (Oct 1982) }\end{array}$ & $\begin{array}{l}\text { Mean } \\
\% \\
\text { Min } \\
\operatorname{Max}\end{array}$ & $\begin{array}{c}0.08 \\
58 \\
0.06 \\
0.10\end{array}$ & $\begin{array}{c}0.18 \\
31 \\
0.10 \\
0.29\end{array}$ & $2.3 \times 10^{7}$ & (2) & $<1 \mu \mathrm{m}$ \\
\hline $\begin{array}{l}\text { Easterm Medit. (Levant basin) } \\
\text { (1983) }\end{array}$ & $\begin{array}{l}\text { Mean } \\
\% \\
\text { Min } \\
\text { Max }\end{array}$ & $\begin{array}{c}0.12 \\
50 \\
0.01 \\
0.28\end{array}$ & $\begin{array}{c}0.13 \\
33 \\
0.00 \\
0.33\end{array}$ & & (3) & 1 yr sampling \\
\hline $\begin{array}{l}\text { Mediterranean Sea } \\
\text { (Jun-Jul 1983) }\end{array}$ & & & & $\begin{array}{l}3.7 \times 10^{6} \\
2.9 \times 10^{7}\end{array}$ & (4) & (75 to $100 \mathrm{~m})$ \\
\hline Ligurian Sea (Jan-Mar 1985) & & 0.45 & & & (5) & \\
\hline Ligurıan Sea (May-Jun 1985) & $\%$ & 50 & & & (6) & $<3 \mu \mathrm{m}$ - surface \\
\hline Ligurıan Sea (Dec 1985) & $\begin{array}{l}\text { Mean } \\
\% \\
\text { Min } \\
\text { Max }\end{array}$ & $\begin{array}{l}0.13 \\
75 \\
0.04 \\
0.27\end{array}$ & $\begin{array}{l}0.38 \\
79 \\
0.07 \\
0.66\end{array}$ & & (7) & Surface \\
\hline Ionian Sea (Nov 1985) & & & & $8.0 \times 10^{6}$ & (8) & Cyanobacteria \\
\hline Algerian Basın (Nov 1985) & & & & $9.8 \times 10^{6}$ & (8) & Cyanobacteria \\
\hline Algenan Basin (May-Jun 1986) & $\%$ & 53 & & & (6) & $<3 \mu \mathrm{m}$ - surface \\
\hline $\begin{array}{l}\text { Tyrrhenian Sea Gulf of Milazzo } \\
\text { (Jul 1986) }\end{array}$ & $\begin{array}{l}\text { Mean } \\
\% \\
\text { Min } \\
\text { Max }\end{array}$ & $\begin{array}{l}0.60 \\
75 \\
0.18 \\
1.80\end{array}$ & $\begin{array}{c}1.02 \\
62 \\
0.11 \\
5.62\end{array}$ & $6.8 \times 10^{7}(9)^{\mathrm{b}}$ & (7) & $\begin{array}{l}\text { Optical depths to } \\
25, \text { light level }\end{array}$ \\
\hline Straits of Messina (Jul 1986) & $\begin{array}{l}\text { Mean } \\
\% \\
\text { Min } \\
\text { Max }\end{array}$ & $\begin{array}{l}0.21 \\
28 \\
0.04 \\
1.00\end{array}$ & $\begin{array}{c}2.18 \\
92 \\
1.57 \\
3.05\end{array}$ & & $(10)$ & \\
\hline Straits of Messina (Oct 1986) & $\begin{array}{l}\text { Mean } \\
\% \\
\text { Min } \\
\operatorname{Max}\end{array}$ & $\begin{array}{c}0.22 \\
50 \\
0.14 \\
0.43\end{array}$ & $\begin{array}{l}1.00 \\
78 \\
0.28 \\
8.96\end{array}$ & & (10) & $<1 \mu \mathrm{m}$ \\
\hline North Adriatic Sea (Apr 1986) & $\begin{array}{l}\text { Mean } \\
\% \\
\text { Min } \\
\text { Max }\end{array}$ & & $\begin{array}{c}1.52 \\
60 \\
0.06 \\
6.81\end{array}$ & & $(7)$ & $\begin{array}{l}\text { Optical depths to } \\
25 \% \text { light level }\end{array}$ \\
\hline $\begin{array}{l}\text { North Adriatic Sea } \\
\text { (Sep 1986) }\end{array}$ & $\begin{array}{l}\text { Mean } \\
\% \\
\text { Min } \\
\text { Max }\end{array}$ & & $\begin{array}{c}1.90 \\
48 \\
0.33 \\
9.81\end{array}$ & $1.5 \times 10^{6}(9)^{\mathrm{b}}$ & (7) & $\begin{array}{l}\text { Optucal depths to } \\
25 \% \text { light level }\end{array}$ \\
\hline Adriatic Sea (1986-87) & $\%$ & $46-85$ & & & (11) & \\
\hline Ligurian Sea (Feb 1987) & $\begin{array}{l}\text { Mean } \\
\% \\
\text { Min } \\
\text { Max }\end{array}$ & $\begin{array}{c}0.42 \\
62 \\
0.24 \\
0.69\end{array}$ & $\begin{array}{c}0.76 \\
58 \\
0.16 \\
1.31\end{array}$ & $6.0 \times 10^{h}(9)^{\mathrm{b}}$ & (7) & Surface \\
\hline Ionian Sed (May 1987) & $\begin{array}{l}\text { Mean } \\
\% \\
\text { Min } \\
\text { Max }\end{array}$ & $\begin{array}{c}0.44 \\
67 \\
0.24 \\
0.69\end{array}$ & $\begin{array}{c}0.26 \\
59 \\
0.13 \\
0.32\end{array}$ & $3.1 \times 10^{5}(9)^{\mathrm{b}}$ & (7) & Surface \\
\hline $\begin{array}{l}\text { Tyrrhenian Sea Eolie Islands } \\
\text { (Jun 1987) }\end{array}$ & $\begin{array}{l}\text { Mean } \\
\% \\
\text { Min } \\
\text { Max }\end{array}$ & $\begin{array}{c}0.04 \\
68 \\
0.02 \\
0.06\end{array}$ & $\begin{array}{c}0.64 \\
91 \\
0.14 \\
2.26\end{array}$ & $4.3 \times 10^{b}(9)^{b}$ & (10) & $\begin{array}{l}\text { Optical depths to } \\
25 \text { light level }\end{array}$ \\
\hline $\begin{array}{l}\text { ¿Sources: } \\
\text { (1) Berman et al. (1984) } \\
\text { (2) Magazzù et al. (1987) } \\
\text { (3) Azov (1986) } \\
\text { (4) Hagström et al. (1988) } \\
\text { (5) Rassoulzadegan et al. (1988) } \\
\text { (6) Raimbault et al. (1988a) } \\
\text { (7) Magazzù et al. (1989a) }\end{array}$ & $\begin{array}{l}\text { (8) Chepurn } \\
\text { (9) Acosta Po } \\
\text { (10) Decemb } \\
\text { (11) Gilmarti } \\
\text { (12) Soto et a } \\
\text { (13) Acosta } \\
\text { (14) Aubert }\end{array}$ & $\begin{array}{l}\text { va \& Gutveyb (1988) } \\
\text { mar (1989) } \\
\text { rini \& Magazzù (1990) } \\
\text { n \& Revelante (1988) } \\
\text { l. (1993) } \\
\text { t al. (1988) } \\
\text { t al. (1989) }\end{array}$ & $\begin{array}{l}\text { (15) Maugeri } \\
\text { (16) Giacobb } \\
\text { (17) Vaulot e } \\
\text { (18) Delgado } \\
\text { (19) Li et al. ( } \\
\text { (20) M. G. Gi } \\
\text { (21) Zaika (1S }\end{array}$ & $\begin{array}{l}\text { et al. }(1992\} \\
\text { et al. }\{1990) \\
\text { al. }(1990) \\
\text { et a) }(1992) \\
992) \\
\text { cobbe (pers. comm.) } \\
86\}\end{array}$ & $\begin{array}{l}\text { (22) Platt e } \\
\text { (23) Magaz } \\
\text { (24) Vaulot } \\
\text { (25) Owen }\end{array}$ & $\begin{array}{l}\text { al. (1985) } \\
\text { zù et al. (1989b) } \\
\text { \& Partensky (1989) } \\
\text { et al. (1989) }\end{array}$ \\
\hline
\end{tabular}


Table 1 (continued)

\begin{tabular}{|c|c|c|c|c|c|c|}
\hline Location & & $\begin{array}{c}\mathrm{Chl} \mathrm{a} \\
\left(\mathrm{mg} \mathrm{m}^{-3}\right)\end{array}$ & $\left(\mathrm{mg} \mathrm{C} \mathrm{m}^{-3} \mathrm{~h}^{-1}\right)$ & $\begin{array}{l}\text { Picophytoplankton } \\
\text { (cells }]^{-1} \text { ) }\end{array}$ & Source" & Comments \\
\hline $\begin{array}{l}\text { Straits of Sicily Western } \\
\text { (Jun 1987) }\end{array}$ & $\begin{array}{l}\text { Mean } \\
\text { Mın } \\
\text { Max }\end{array}$ & $\begin{array}{l}0.05 \\
68 \\
0.02 \\
0.11\end{array}$ & $\begin{array}{c}0.61 \\
82 \\
0.18 \\
1.03\end{array}$ & $5.4 \times 10^{6}(9)^{b}$ & (7) & Surface \\
\hline $\begin{array}{l}\text { Straits of Sicily Eastern } \\
\text { (Oct 1987) }\end{array}$ & $\begin{array}{l}\text { Mean } \\
\% \\
\text { Min } \\
\text { Max }\end{array}$ & $\begin{array}{l}0.02 \\
67 \\
0.01 \\
0.04\end{array}$ & $\begin{array}{l}0.58 \\
77 \\
0.09 \\
1.87\end{array}$ & $8.8 \times 10^{5}(9)^{b}$ & $(10)$ & Surface \\
\hline $\begin{array}{l}\text { Northwest Medit. Rhone River } \\
\text { plume (Jan-Oct 1988) }\end{array}$ & $\operatorname{Max}$ & & & $2.0 \times 10^{6}$ & (12) & euphotic layer \\
\hline Ligurian Sea (Feb 1988) & $\begin{array}{l}\text { Mean } \\
\% \\
\text { Min } \\
\text { Max }\end{array}$ & $\begin{array}{c}0.58 \\
71 \\
0.28 \\
0.88\end{array}$ & $\begin{array}{l}0.69 \\
64 \\
0.18 \\
2.46\end{array}$ & $1.4 \times 10^{8}(9)^{b}$ & $(10)$ & $\begin{array}{l}\text { Optical depths to } \\
25 \% \text { light level }\end{array}$ \\
\hline Ionian Sea (Jun 1988) & $\begin{array}{l}\text { Mean } \\
\% \\
\text { Min } \\
\text { Max }\end{array}$ & $\begin{array}{l}0.05 \\
65 \\
0.03 \\
0.08\end{array}$ & $\begin{array}{c}1.64 \\
92 \\
0.23 \\
3.39\end{array}$ & $2.0 \times 10^{5}(9)^{6}$ & (10) & $\begin{array}{l}\text { Optical depths to } \\
25 \% \text { light level }\end{array}$ \\
\hline $\begin{array}{l}\text { Straits of Messina } \\
\text { (Jul } 1988 \text { and } 1989 \text { ) }\end{array}$ & $\begin{array}{l}\text { Mean } \\
\% \\
\text { Min } \\
\text { Max }\end{array}$ & $\begin{array}{c}0.12^{\circ} \\
35^{\circ} \\
0.00^{\circ} \\
0.62^{\circ}\end{array}$ & & $\begin{array}{c}7.1 \times 10^{6} \cdot(15)^{b} \\
1.0 \times 10^{6} \\
4.7 \times 10^{7}\end{array}$ & (14) & $\begin{array}{l}\text { Water column } \\
\text { "only } 1988\end{array}$ \\
\hline $\begin{array}{l}\text { Straits of Sicily } \\
\text { (Sep 1988 and Jun 1989) }\end{array}$ & $\begin{array}{l}\text { Mean } \\
\text { Min } \\
\text { Max }\end{array}$ & & & $\begin{array}{l}1.7 \times 10^{7} \\
2.2 \times 10^{6} \\
3.0 \times 10^{7}\end{array}$ & $(16)$ & (16) \\
\hline $\begin{array}{l}\text { Northwest Medit. } \\
\text { (Dec } 1988 \text { and Jan 1989) }\end{array}$ & $\begin{array}{l}\text { Mean } \\
\% \\
\text { Mun } \\
\text { Max }\end{array}$ & $\begin{array}{l}0.02 \\
31 \\
0.00 \\
0.13\end{array}$ & & $\begin{array}{l}1.9 \times 10^{7} \\
1.0 \times 10^{6} \\
5.0 \times 10^{7}\end{array}$ & (17) & Prochlorophytes \\
\hline $\begin{array}{l}\text { Northwest Medit. } \\
\text { (Dec } 1988 \text { and Jan 1989) }\end{array}$ & $\begin{array}{l}\text { Min } \\
\text { Max }\end{array}$ & & & $\begin{array}{l}5.0 \times 10^{5} \\
3.0 \times 10^{7}\end{array}$ & (24) & $\begin{array}{l}\text { Cyanobacteria } \\
\text { surface }\end{array}$ \\
\hline $\begin{array}{l}\text { Northwest Medit. } \\
\text { (Jan 1989) }\end{array}$ & $\begin{array}{l}\text { Mean } \\
\%\end{array}$ & & $\begin{array}{c}488^{\circ} \\
61\end{array}$ & & $(25)$ & $\begin{array}{l}\cdot \mathrm{mgC} \mathrm{m} \mathrm{Cl}^{-2} \mathrm{~d}^{-1} \\
\%<5 \mu \mathrm{m}\end{array}$ \\
\hline $\begin{array}{l}\text { Catalan Sea } \\
\text { (May 1989) } \\
\text { (Feb 1990) }\end{array}$ & $\begin{array}{l}\text { Min } \\
\text { Max } \\
\text { Min } \\
\text { Max }\end{array}$ & & & $\begin{array}{l}8.0 \times 10^{4} \\
7.3 \times 10^{7} \\
8.0 \times 10^{4} \\
5.1 \times 10^{7}\end{array}$ & (18) & $\begin{array}{l}\text { Synechococcus } \\
\text { Synechococcus } \\
\text { Synechococcus } \\
\text { Synechococcus }\end{array}$ \\
\hline $\begin{array}{l}\text { Tyrrhenian Sea Gulf of Policastro } \\
\text { (Oct 1990) }\end{array}$ & $\begin{array}{l}\text { Mean } \\
\text { Mean }\end{array}$ & & & $\begin{array}{l}1.8 \times 10^{6} \\
2.0 \times 10^{7}\end{array}$ & & $\begin{array}{l}\text { Eukaryotic }(1-2 \mu \mathrm{m}) \\
\text { Cyanobacteria }\end{array}$ \\
\hline $\begin{array}{l}\text { Northwest Medit. Gulf of Valentia } \\
\text { (Jul 1993) }\end{array}$ & Mean & & & $1.4 \times 10^{8}$ & (20) & $\begin{array}{l}\text { Cyanobacteria } \\
\text { Surface }\end{array}$ \\
\hline $\begin{array}{l}\text { Northwest Medit. Gulf of Lions } \\
\text { (Jul 1993) }\end{array}$ & Mean & & & $9.2 \times 10^{6}$ & (20) & $\begin{array}{l}\text { Cyanobacteria } \\
\text { Surface }\end{array}$ \\
\hline Ligurian Sea (Jul 1993) & Mean & & & $1.3 \times 10^{7}$ & (20) & $\begin{array}{l}\text { Cyanobacteria } \\
\text { Surface }\end{array}$ \\
\hline Northwest Medit. & Mean & & $8.10^{\circ}$ & $1.1 \times 10^{7}$ & (21) & $\cdot m g C m^{-3} d^{-1}$ \\
\hline Villefranche-sur-Mer & $\%$ & & 57 & $3.6 \times 10^{7}$ & & \\
\hline $\begin{array}{l}\text { Lake Faro brackish lagoon } \\
\text { (Oct 1982) }\end{array}$ & $\begin{array}{l}\text { Mean } \\
\%\end{array}$ & $\begin{array}{c}0.30 \\
16\end{array}$ & $\begin{array}{c}1.9 \\
9\end{array}$ & $1.8 \times 10^{7}$ & (22) & Surface \\
\hline $\begin{array}{l}\text { Lake Faro brackish lagoon } \\
\text { (Mar-Dec 1986) }\end{array}$ & $\begin{array}{l}\text { Mean } \\
\% \\
\text { Min } \\
\text { Max }\end{array}$ & $\begin{array}{c}5.03 \\
26 \\
1.02 \\
16.9\end{array}$ & $\begin{array}{l}3.35 \\
38 \\
0.92 \\
11.1\end{array}$ & $\begin{array}{l}4.3 \times 10^{5} \\
3.3 \times 10^{7}\end{array}$ & (13) & Water column \\
\hline $\begin{array}{l}\text { Lake Faro brackish lagoon } \\
(1987-1988)\end{array}$ & $\begin{array}{l}\text { Mean } \\
\% \\
\text { Min } \\
\text { Max }\end{array}$ & $\begin{array}{l}1.58 \\
11 \\
0.07 \\
4.36\end{array}$ & $\begin{array}{c}3.04 \\
41 \\
0.10 \\
28.70\end{array}$ & $1.1 \times 10^{8}(9)^{\mathrm{b}}$ & (23) & Water column \\
\hline $\begin{array}{l}\text { Lake Ganzirri brackish lagoon } \\
(1987-1988)\end{array}$ & $\begin{array}{l}\text { Mean } \\
\% \\
\text { Min } \\
\text { Max }\end{array}$ & $\begin{array}{l}2.56 \\
8 \\
0.00 \\
14.8\end{array}$ & $\begin{array}{c}3.36 \\
8 \\
0.07 \\
17.098\end{array}$ & & (23) & Water column \\
\hline
\end{tabular}


The cellular densities reported range from $2.0 \times 10^{5}$ to $1.4 \times 10^{8}$ cells $1^{-1}$ and show a mean value of $2.0 \times 10^{7}$ cells $1^{-1}$. While reports give a range of 3 orders of magnitude, most values were around $10^{7}$ and supports the hypothesis of the existence, in marine waters, of a stationary equilibrium of these organisms.

Most of the published works mainly refer to the Cyanobacteria cells, and the eukaryotic component appears to be at least 1 order of magnitude less abundant (Delgado et al. 1992). This assertion seems to be supported by the fact that the $0.5-1.0 \mu \mathrm{m}$ portion (presumably prokaryotic) shows a higher percentage of biomass and ${ }^{14} \mathrm{C}$ assimilation (Decembrini \& Magazzù 1990).

Finally, Prochlorophytes have been found in densities of $10^{7}$ cells $1^{-1}$ in different environments and seasonal periods (Vaulot et al. 1990, Li et al. 1992). It is interesting to note that these small organisms, that are 1.6 times more abundant than Synechococcus (Vaulot et al. 1990), may represent $60 \%$ (in chl a) of the total prokaryotic component and show a vertical distribution with the maximum density $\left(5 \times 10^{7}\right.$ cells $1^{-1}$; Vaulot et al. 1990) at the sea surface differing from that observed in the oceans (Chisholm et al. 1988).

Table 2. Percentage of biomass and ${ }^{14} \mathrm{C}$ assimilation of picophytoplankton in the different Mediterranean areas. P: pelagic; $N$ : neritic

\begin{tabular}{|c|c|c|c|c|}
\hline Location & Environment & Chl a & ${ }^{14} \mathrm{C}$ & Source \\
\hline \multirow[t]{4}{*}{ Straits of Messina } & $\mathrm{P}$ & 58 & 31 & (2) \\
\hline & $\mathrm{P}$ & 28 & 92 & $(10)$ \\
\hline & $\mathrm{P}$ & 50 & 78 & $(10)$ \\
\hline & $\mathrm{P}$ & 35 & & (14) \\
\hline \multirow[t]{4}{*}{ Ligurian Sea } & $\mathrm{P}$ & 50 & & $(6)$ \\
\hline & $\mathrm{P}$ & 75 & 79 & (7) \\
\hline & $\mathrm{P}$ & 62 & 58 & (7) \\
\hline & $P$ & 71 & 64 & $(10)$ \\
\hline \multirow[t]{2}{*}{ Tyrrhenian Sea } & $\mathrm{N}$ & 75 & 62 & (7) \\
\hline & $\mathrm{P}$ & 68 & 91 & $(10)$ \\
\hline \multirow[t]{2}{*}{ Straits of Sicily } & $P$ & 68 & 82 & (7) \\
\hline & $\mathrm{P}$ & 67 & 77 & $(10)$ \\
\hline \multirow[t]{2}{*}{ Ionian Sea } & $\mathrm{p}$ & 67 & 59 & (7) \\
\hline & $\mathrm{P}$ & 65 & 92 & (10) \\
\hline \multirow[t]{3}{*}{ Adriatic Sea } & $N$ & 66 & & (11) \\
\hline & $N$ & & 60 & (7) \\
\hline & $N$ & & 48 & (7) \\
\hline \multirow[t]{5}{*}{ Levant Basin } & $N$ & 50 & 21 & (3) \\
\hline & $\mathrm{P}$ & 50 & 44 & (3) \\
\hline & Mean & 59 & 65 & \\
\hline & Pelagic & 57 & 71 & \\
\hline & Neritic & 64 & 44 & \\
\hline \multicolumn{5}{|l|}{${ }^{\circledR}$ See Table 1} \\
\hline
\end{tabular}

\section{Picophytoplankton in brackish environments}

The contribution of picophytoplankton studied during an annual cycle in 2 brackish eutrophic environments in Sicily (Lakes Faro and Ganzirri) turned out to be clearly lower than in marine waters both in terms of chl a biomass $(11.7 \%)$ and of ${ }^{14} \mathrm{C}$ assimilation $(19.3 \%)$ (Magazzù et al. 1989b). These low percentages are in agreement with previous results (Table 1) (Platt et al. 1985, Acosta et al. 1988).

In such environments this important decrease could be due to the competition between organisms of different size in assimilation and utilization of nutrients. According to Fogg (1986), in oligotrophic waters, picophytoplankton are able, due to larger cellular surfaces, to assimilatc nutrients more efficiently than bigger phytoplanktonic organisms. The latter, however, seem to possess a higher assimilation kinetics in environments where nutrients are abundant, as in the eutrophic ones. Furthermore, the fact that for the smaller fraction the ratio $\mathrm{P} / \mathrm{B}$ is always higher (Decembrini \& Magazzù 1990) supports the thesis that these organisms possess better photosynthetic capabilities per biomass unit.

\section{Conclusion}

Despite the difficulties of comparing studies based on different methodologies, the results available on the Mediterranean Sea confirm that picophytoplankton are ubiquitous in these waters and that values on production, biomass and cellular abundance correspond to data obtained in the world's oceans (Stockner \& Antia 1986, Li \& Platt 1987). The contribution of the fraction $<2.0 \mu \mathrm{m}$ to the total primary production is more important in oligotrophic off-shore waters, compared to phytoplankton $>2.0 \mu \mathrm{m}$, reaching a mean percentage of $71 \%$ in pelagic areas and dropping to $44 \%$ in neritic waters. In agreement with the observation of Raimbault et al. (1988b) the $<2.0 \mu \mathrm{m}$ fraction rarely exceeds certain levels in temperate Mediterranean waters; therefore, seasonal variations in biomass and primary production are to be ascribed to the nano fraction $(20-2 \mu m)$ and eutrophication phenomena to the netphytoplankton cells larger than $20 \mu \mathrm{m}$.

The extremely small dimensions of these organisms favour their neutral buoyancy and therefore offer the possibility of providing nutrients through molecular diffusion (a mechanism able to replace consumed nutrients within the water microsphere surrounding the cell) or through the microbial food-chain processes described by Goldman (1984). Furthermore, the higher cellular density $\left(10^{7}\right.$ cells $\left.1^{-1}\right)$ which is doubled when procaryotic organisms belonging to Prochlorophytes 
are included, and the augmented cellular surface probably permit a more efficient supply of nutrients compared to the bigger fraction.

Data available on biomass and production do not permit conclusions on a possible seasonal cycle showing differences between summer and winter. However, the quite stationary cellular abundance around $10^{7}$ cells $1^{-1}$ throughout the different seasons suggests that physiological mechanisms or some form of inhibition, or grazing itself, are active in regulating its development.

\section{LITERATURE CITED}

Acosta Pomar MLC (1989) Ecologia e distribuzione del picofitoplancton in ambiente marino e salmastro Tesi di Dottorato, Università di Messina

Acosta Pomar L, Bruni V, Decembrini F, Giuffrè G, Maugeri TL (1988) Distribution and activity of picophytoplankton in a brackish environment. Prog Oceanogr 21:129-138

Aubert M. Magazzù G et al. (1989) Mers d'Europe. Études hydrologiques, chimiques et biologiques, Vol 1, Détroit de Messine. Rev Int Océanogr Méd 55/56:1-88

Azov Y (1986) Seasonal patterns of picoplankton productivity and abundance in nearshore oligotrophic waters of the levantine Basin (Mediterranean). J Plankton Res 8:41-43

Berland BR, Maestrini SY, Burlakova ZP, Georgieva L, Kholodov VY, Krupatkina DK (1990) Limitation de la croissance algale dans les eaux ultra-oligotrophes de la mer du Levant (Méditerranée orientale). Mem Biol mar Oceanogr 18: $5-28$

Berman TY, Azov Y, Townsend D (1984) Understanding oligotrophic oceans. Can the eastern Mediterranean be a useful model? In: Holm-Hansen O, Bolis L, Giles R (eds) Marine phytoplankton and productivity: lecture notes on coastal and estuarine studies. Springer-Verlag, Berlin, p $101-112$

Chepurnova EA, Gutveyb LG (1988) Distribution and size structure of phototrophic bacterioplankton (Cyanobacteria) in the Mediterranean Sea and Atlantic Ocean. Oceanology 28(5):643-647

Chisholm SW. Olson RJ, Zettler ER, Goericke R, Waterbury JB, Welschmeyer NA (1988) A novel free-living prochlorophyte abundant in the oceanic zone. Nature 334:340-343

Decembrini F, Magazzù G (1990) Clorofilla, numero di assimilazione e ATP del picoplancton fotosintetico nei mari italiani. Oebalia 16(1):443-456

Delgado M. Latasa M, Estrada M (1992) Variability in the size-fractionated distribution of the phytoplankton across the Catalan front of the north-west Mediterranean. J Plankton Res 14(5):753-771

Fogg GE (1986) Picoplankton. Proc R Soc Lond 228:1-30

Giacobbe MG, La Ferla R, Maimone G, Crisafi E (1990) Relationship between coccoid cyanobacteria and larger size phytoplankton. Monitoring in nearshore waters of Sicily, Italy. Mem Biol Mar Oceanogr 18:55-66

Gilmartin M, Revelante N (1988) Observation on the relative contribution of pico-and nanoplancton to the subsurface chlorophyll maximum in the Northern Adriatic Sea. Rapp Comm int Mer Médit 31(2):225

Goldman JC (1984) Oceanic nutrient cycles In: Fasham MJR (ed) Flows of energy and materials in marine ecosystems: theory and practice. Plenum Pless, New York, p 137-170
Hagström A, Azam F, Anderson A, Wiker J, Rassoulzadegan F (1988) Microbial loop in an oligotrophic pelagic marine ecosystem: possible roles of cyanobacteria and nanoflagellates in the organic fluxes. Mar Ecol Prog Ser 49: $171-178$

lbarra SO (1981) Contributions relatives du micro- et du nanoplancton à la production primaire dans une zone cotière de Méditerranée Nord-occidentale. Vie Milieu 31(2): 119-128

Johnson PW, Sieburth JMCN (1982) In situ morphology and occurrence of eucaryotic phototrophs of bacterial size in the picoplankton of estuarine and oceanic waters. J Phycol $8: 318-327$

Li WKW, Platt $T$ (1987) Photosynthetic picoplankton in the ocean. Sci Prog Oxf 71:117-132

Li WKW, Wood AM (1988) Vertical distribution of north Atlantic ultraphytoplankton: analysis by flow cytometry and epifluorescence microscopy. Deep Sea Res 35: $1615-1638$

Li WKW, Lewis MR, Lister A (1992) Flow cytometric detection of prochlorophytes and cyanobacteria in the Gulf of Policastro, Italy. Arch Hydrobiol 42:1-8

Lohmann H (1911) Über das Nannoplankton und die Zentrifugieren kleinster Wasserphoben zur Gewinnung derselben Zustände. Int Revue ges Hydrobiol Hydrogr 4:1-38

Magazzù G, Bruni V, Piccione A, Platt T, Irwin, Subba Rao DV (1987) Picoplankton: contribution to phytoplankton production in the Straits of Messina. Mar Ecol 8:21-31

Magazzù G, Bruni V, Decembrini F, Panella S (1989a) La produzione primaria del picoplancton fotosintetico nei mari italiani. Oebalia 4:463-478

Magazzù G, Decembrini F, Pulicanò G (1989b) Andamento temporale della biomassa e della produzione primaria del picofitoplancton nel complesso lagunare di Faro e Ganzirri (Messina). Nova Thalassia 10(1):135-155

Maugeri TL, Acosta Pomar MLC, Bruni V, Salomone L (1992) Picoplankton and picophytoplankton in the Ligurian Sea and in the Straits of Messina (Mediterranean Sea). Bot mar 35:493-502

Owens NJP, Rees AP, Woodward EMS, Mantoura RFC (1989) Size-fractionated primary production and nitrogen assimilation in the North-Western Mediterranean Sea during January 1989. In: Martin JM, Barth H (eds) Water pollution research report, Vol 13: EROS 2000 (European River Ocean System) project workshop. CEC, Brussels, p $126-135$

Neveux J, Vaulot D, Courties C, Fukai E (1989) Green photosynthetic bacteria associated with the deep chlorophyll maximum of the Sargasso Sea. Cr Acad Sci Paris, Sér III, $308: 9-14$

Platt T, Subba Rao DV, Irwin B (1985) Photosynthesis by picoplankton in the Lago di Faro - Messina (Sicily). Mem Biol mar Oceanogr 15:61-70

Raimbault P, Taupier-Letage I, Rodier M (1988a) Vertical distribution of phytoplankton in the western Mediterranean Sea during early summer. Mar Ecol Prog Ser 45:153-158

Raimbault P, Rodier M, Taupier-Letage I (1988b) Size fraction of phytoplankton in the Ligurian Sea and the Algerian Basin (Mediterranean Sea): size distribution versus total concentration. Mar microb Food Webs 3(1):1-7

Rassoulzadegan F, Laval-Peuto M, Sheldon RW (1988) Partitioning of the food ration of marine ciliates between picoand nanoplankton. Hydrobiologia 159:75-88

Sieburth JMcN, Smetacek V, Lenz J (1978) Pelagic ecosystem structure: heterotrophic compartments of the plankton and their relationship to plankton size fractions. Limnol Oceanogr 23:1256-1263 
Soto Y, Bianchi M, Martinez J, Vives Rego G (1993) Seasonal evolution of microplanktonic communities in the estuarine front ecosystem of the Rhone River plume (north-western Mediterranean Sea). Estuar coast Shelf Sci $37: 1-13$

Stockner JG, Antia NJ (1986) Algal picoplankton from marine and freshwatwer ecosystems: a multidisciplinary perspective. Can J Fish Aquat Sci 43:2472-2503

Vaulot D, Partensky F (1988) Winter distribution of marine cyanobacteria (Synechococcus spp.) in the North-Western Mediterranean Sea. In: Martin JM, Barth H (eds) Water pollution research report, Vol 13: EROS 2000 (European
River Ocean System) project workshop. CEC, Brussels, p $136-149$

Vaulot D, Partensky F, Neveux J, Mantoura RFC, Llewellyn CA (1990) Winter presence of prochlorophytes in surface waters of the northwestern Mediterranean Sea. Limnol Oceanogr 35(5): 1156-1164

Vercelli F, Picotti M (1926) Crociere per lo studio dei fenomeni nello Stretto di Messina. Comm Inter del Mediterraneo, Venezia, p 1-161

Zaika VYe (1986) Vertical distribution of autotrophic picoplankton in the Indian Ocean and the Mediterranean Sea. Oceanology 6(2):209-212 


\section{BOOK REVIEWS}

Johanna Laybourn-Parry (1992). Protozoan Plankton Ecology. Chapman \& Hall, London. 231 p. Hardbound. \$52. ISBN 0412-34440-8.

Based on the title, this book invites comparison with existing titles on protistan ecology such as Fenchel's Ecology of Protozoa or Capriulo's volume on the Ecology of Marine Protozoa. However, it is aimed at a very different audience and contains a different mixture of information. Protozoan Plankton Ecology is meant as an introduction to the topic for advanced undergraduates, beginning graduate students and researchers unfamiliar with protists.

As the use of term 'protozoa' might imply, autotrophic protists are not treated. An introduction to the groups and roles of heterotrophic and mixotrophic forms in both freshwater and saltwater systems is the stated goal and the book is very clearly destined to be used in the classroom. The first chapter is a brief introduction to the basic physical characteristics of lakes, estuaries and oceans (streams and rivers are ignored throughout). The major groups of protists (ciliates, 'flagellates', sarcodines) are then introduced. Basics of protozoan physiology (metabolism, growth, nutrition, excretion) are covered in the third chapter. The next 2 chapters treat 'distribution and occurrence' in lakes and saltwater systems. Rather oddly, the functional role of protozooplankton comes last.

The level of the text, approximately first year university biology, can be viewed as an advantage or disadvantage. The book is accessible; for example, a glossary is not needed to follow the text. However, much of the material is presented simplistically or strangely, and some important topics are neglected. A case in point is ciliate feeding. Data from Verity's (1985) study of tintinnid feeding, which shows a decrease in clearance rate with food concentration (classic curvilinear functional response), is presented as an example of 'optimal foraging' among protozoa. I think it is stretching things a bit to call declines in filtration rates with increases in food concentration an ability to modulate the filtering rate (that) ensures that energy is not wasted by filtering at an unnecessarily high rate when food is abundant'. Such a divergence is included while the physiology and anatomy of feeding in protists, which after all distinguishes them from bacteria with extra-cellular digestion and metazoans with gut tracts, is not presented.
The book, like many first editions, has more than its fair share of mistakes: an upside-down Strombidium, inappropriate figure legends (concentrations of chlorophyll a as $1^{\circ}$ production), etc. The graphics leave much to be desired - many appear to have been assembled by hand. These may be petty details, but for me they can spoil the pleasure of reading a new book.

Despite these flaws, Protozoan Plankton Ecology is the only text I know of devoted to planktonic protists of freshwater and saltwater systems and it is relatively inexpensive. It may serve as useful supplementary text for courses in protozoology, limnology or biological oceanography.

John R. Dolan

Paul F. Kemp, Barry F. Sherr, Evelyn B. Sherr, Jonathan Cole (eds) (1993). Handbook of Methods in Aquatic Microbial Ecology. Lewis Publishers (CRC Press), Boca Raton, FL, USA. 777 p. \$130. ISBN 0-87371-564-0.

It's big, it's yellow, and it's not cheap - so do you need it? This collection of methods can serve as a very useful introduction to almost any method one cares to name (even and especially the most esoteric) and there's the rub - only an introduction and a recipe. The chapters, each by separate authors, represent a single method. Thus, the topic of 'bacterial production' is covered by separate authors presenting the measurement of RNA and DNA synthesis, ATP turnover, ${ }^{3} \mathrm{H}-\mathrm{THY}$ (planktonic), ${ }^{3} \mathrm{H}-\mathrm{THY}$ (benthic), ${ }^{3} \mathrm{H}$-LEU, etc. For most of the chapters, there is little or no attempt to critically examine the method nor are all the assumptions involved necessarily presented. Some very basic methods are not included as separate chapters (e.g. choices of fixatives for protists, or DAPI staining despite the fact that we are still not sure what those little blue dots really represent). However, one will find 2 chapters on flow cytometry as if a researcher, after reading, might run out and buy one or perhaps have an unused flow cytometer laying about.

In my view, the book is a great catalogue and introduction to the literature. The editors somehow managed to pull together a staggering quantity of methods. The book is well worth its price but don't expect 'Methods for the Complete Idiot' or 'Critical Examinations of Methodologies'.

John R. Dolan 
R. Guerro, C. Pedros-Alio (eds) (1993). Trends in Microbial Ecology. Proceedings of the Sixth International Symposium on Microbial Ecology, Barcelona, 6-11 September 1992. Spanish Society for Microbiology. 717 p. Hardbound. ISBN 84-604-7996. Available from ISME-6 Secretariat, Apartado 16009, E-08080 Barcelona, Spain.

This volume consists of 143 papers authored by speakers invited to the 6th Microbial Ecology Symposium. The papers cover an enormous range of topics. Each of them serves as a tasty hors d'œuvre, pleasing the palate but frustrating the appetite because they are all short ( 3 to 5 pages), really little more than extended abstracts with abbreviated bibliographies. The value of such a collection of papers to individual workers will likely depend on the number of papers of interest. So, rather than trying to mention who and what is included and who is not, topics covered and the number of papers which appear are listed below, following the editor's arrangement.

I. Physiological ecology

a) Extreme conditions: 8

b) Phototrophic microorganisms: 4

c) Metabolic capabilities: 11

c) Surfaces: 5

d) Gradients: 6

e) Starvation: 5
II. Interactions among populations

a) Interactions with animals; 7

b) Interactions with plants: 10

c) Interactions among microorganisms: 2

d) Interactions with viruses: 5

e) Transfer of genetic material among microorganisms: 5

III. Community ecology

a) Community structure: 10

b) Microbial food webs: 9

c) Cycling of elements and global ecology: 11

IV. Systematics and evolution of microorganisms

a) Methods for in situ identification of microorganisms: 5

b) Strategies for isolation of new microorganisms: 6

c) Microbial species and their evolution: 5

V. Applied microbiology

a) Environmental virology: methods and problems: 7

b) Bioremediation: 4

c) Crop productivity: 5

d) Biodeterioration: 3

e) Medical microbial ecology: 5

John R. Dolan 